\title{
Herbicide Selectivity in Alfalfa Crops ${ }^{1}$
}

\author{
Seletividade de Herbicidas na Cultura da Alfafa
}

HIJANO, N. ${ }^{2}$, MONQUERO, P.A. ${ }^{2}$, MUNHOZ, W.S. ${ }^{2}$, and GUSMÃO, M.R. ${ }^{3}$

\begin{abstract}
This study aimed to determine the selectivity of herbicides applied in pre- and post-emergence for alfalfa crops. Three separate experiments were carried out under greenhouse conditions. The first experiment was arranged in a completely randomized design with three replications in a $4 \times 11+1$ factorial scheme, with eleven herbicides (bentazon, chlorimuron-ethyl, fomesafen, fluazifop-p-butyl, saflufenacil, imazethapyr, clethodim, nicosulfuron, imazaquin, haloxyfop-methyl and MSMA), four doses of each herbicide (0.5 D, $0.75 \mathrm{D}, 1.0 \mathrm{D}$ and $1.25 \mathrm{D}$, where $\mathrm{D}=$ recommended dose), plus an untreated control. The products were applied to alfalfa plants at the stage of 4 to 5 leaf pairs. In the second experiment, the effect of pre-emergent herbicides on early alfalfa development was observed through a completely randomized design with five replications in a $3 \times 4 \times 2$ factorial scheme, with three herbicides (hexazinone, atrazine + simazine, S-metolachlor), four doses (0.5 D, $0.75 \mathrm{D}, 1.0 \mathrm{D}$ and $1.25 \mathrm{D}$ ), and two types of soil texture (loamy and clay soil), plus an untreated control. The third experiment evaluated the action of atrazine, 2,550 $\mathrm{g} \mathrm{ha}^{-1}$; clomazone $600 \mathrm{~g} \mathrm{ha}^{-1}$; diclosulam - $25 \mathrm{~g} \mathrm{ha}^{-1}$; diuron+hexazinone - $936+264 \mathrm{~g}^{\text {ha-1 }}$ and diuron+hexazinone + sulfometuron $-1,386+391+33.35 \mathrm{~g} \mathrm{ha}^{-1}$ on alfalfa sown at different times after herbicide application. The effects of the treatments on alfalfa were evaluated according to visual phytotoxicity symptoms, plant height, and biomass of roots and shoots. Among the herbicides applied at post-emergence, imazethapyr, clethodim, haloxyfop-p-methyl and MSMA were selective for alfalfa, while among those applied at pre-emergence, none were selective, regardless of soil texture. The results of the third experiment showed that the herbicides diclosulam, hexazinone + diuron and atrazine caused less toxicity in alfalfa plants.
\end{abstract}

Keywords: phytotoxicity, Medicago sativa, residual period.

RESUMO - O objetivo desta pesquisa foi verificar a seletividade de herbicidas aplicados em pré e pós-emergência para a cultura da alfafa. Esta pesquisa foi composta por três experimentos distintos, realizados em casa de vegetação. O primeiro experimento foi conduzido em delineamento experimental inteiramente casualizado com três repetições, em esquema fatorial $11 \times 4+1$, sendo onze herbicidas (bentazon, chlorimuron-ethyl, fomesafen, fluazifop-p-butil, saflufenacil, imazethapyr, cletodim, nicosulfuron, imazaquim, haloxyfop-methyl e MSMA), quatro doses de cada herbicida (0,5D, 0,75D, $1, O D$ e 1,25D, sendo $D=$ dose comercial), mais a testemunha, sem aplicação. Os produtos foram pulverizados sobre as plantas de alfafa no estádio de 4 a 5 pares de folhas. No segundo experimento, com herbicidas aplicados em pré- emergência, o delineamento experimental foi inteiramente casualizado com cinco repetições, em esquema fatorial $3 \times 4 \times 2$, sendo três herbicidas para uso em préemergência (hexazinone, atrazina+simazine, S-metolachlor), quatro doses $(0,5 D, 0,75 D, 1,0 D$ e 1,25D) e dois tipos de solo quanto à textura (argilosa e média), e testemunha sem aplicação de herbicidas. No terceiro experimento, verificou-se a ação de atrazina $\left(2.550 \mathrm{~g} \mathrm{ha}^{-1}\right)$, clomazone $\left(600 \mathrm{~g} \mathrm{ha}^{-1}\right)$, diclosulam (25 $\left.\mathrm{g} \mathrm{ha}^{-1}\right)$, diuron+hexazinone $\left(936+264 \mathrm{~g} \mathrm{ha}^{-1}\right)$ e diuron thexazinone+sulfometuron $\left(1.386+391+33,35 \mathrm{~g} \mathrm{ha}^{-1}\right)$ sobre a alfafa semeada em diferentes épocas após a aplicação dos herbicidas. Os efeitos dos tratamentos sobre a cultura da alfafa foram avaliados de acordo com os sintomas visuais de toxicidade, altura das plantas e biomassa do sistema radicular e da parte aérea. Entre os herbicidas aplicados em pós-emergência, imazethapyr, clethodim, haloxyfop-p-methyl e MSMA foram seletivos para a cultura da alfafa; para os aplicados em pré-emergência, nenhum deles

1 Recebido para publicação em 19.10.2012 e aprovado em 9.5.2013.

2 Universidade Federal de São Carlos, São Carlos-SP, Brasil, Bolsista FAPESP, <pamonque@cca.ufscar.br>; ${ }^{3}$ Embrapa Pecuária Sudeste, São Carlos-SP, Brasil.

Planta Daninha, Viçosa-MG, v. 31, n. 4, p. 903-918, 2013 
foi seletivo, independentemente da textura do solo. Os resultados do terceiro experimento indicam que os herbicidas diclosulam, diuron thexazinone e atrazina provocaram menos toxicidade às plantas de alfafa.

Palavras-chave: fitotoxicidade, Medicago sativa, período residual.

\section{INTRODUCTION}

Weed competition is one of the most limiting factors for the establishment of alfalfa crops, because the initial growth of the culture is slow and the weeds emerging after sowing can reduce the establishment of alfalfa (Zimdahl, 2004). Biomass quality and yield and stability of dry matter production during cultivation are directly associated with the interference of weeds which compete with alfalfa for water, light and nutrients. Studies have shown that weed competition during the rainy season (spring-summer) reduced crop yield by $60 \%$, reaching a $75 \%$ decrease in dry biomass yield. Additionally, weeds can reduce the longevity of alfalfa from five to two years, with a significant decrease in the number of cuts or in grazing (Rassini et al. 1995).

Weed management in alfalfa crops is a major constraint to the production and use of this forage crop as input in dairy production. Spacing between cultivated plants is small; therefore, the mechanical control of weeds is difficult, and manual control is very slow and restricted to small areas. The use of herbicides is an alternative for larger areas. Several herbicides have been used in other countries to control weeds in alfalfa. In Brazil, only the herbicides trifluralin, imazethapyr in early post-emergence (5-10 days after planting alfalfa) and fluazifop-butyl are widely used (Rassini et al., 2007).

Although alfalfa is a major crop in forage production, there are few studies on herbicide selectivity for this species, which highlights the importance of further research, as the most aggravating aspect is the difficulty in controlling eudicotyledonous species (Fontes et al. 1994). Among the latifolicide herbicides which can be used at post-emergence in alfalfa crops, inhibitors of acetolactate synthase (ALS) are particularly important, especially the herbicides chlorimuron-ethyl and nicosulfuron. They have a broad spectrum of activity and are widely used for weed control in soybean and corn crops, respectively (Rodrigues \& Almeida, 2011).

In weed control assays in areas cultivated with alfalfa, the herbicides clethodim and haloxyfop-p-methyl were highly effective in controlling Cynodon dactylon, Echinochloa crus-galli and Setaria parviflora. The 2,4-DB herbicide was effective against Onopordum acanthium, Coronopus didymus, Rapistrum rugosum and Brassica rapa, but no effect was observed in the production of alfalfa. Chlorimuron, flumetsulam and glyphosate were effective against Urtica urens, Stellaria media, Chenopodium album, Xanthium spinosum and Veronica persica, but these herbicides cause phytotoxicity to alfalfa, reducing its production (Arregi et al., 2001).

Furthermore, planting alfalfa after other crops such as corn, beans, sugar cane and soybean is common in dairy farms that have diversified production. Therefore, knowledge of the residual period of herbicides applied to previous crops is crucial to avoid phytotoxicity in alfalfa crops.

To encourage the continued growth in the production of alfalfa in Brazil, it is important to identify herbicides that act on grasses and broadleaved species and are selective to alfalfa. Therefore, the aim of this study was to evaluate the selectivity and the residual period of herbicides applied to alfalfa crops in many different periods.

\section{MATERIAL AND METHODS}

\section{Evaluation of the selectivity of herbicides applied to alfalfa crops at post-emergence}

The experiment was conducted in a greenhouse. The sampling unit was represented by $5 \mathrm{~L}$ polyethylene pots containing soil classified as Haplortox (Embrapa, 1999), collected in the $0-20 \mathrm{~cm}$ layer, whose chemical analysis is shown in Table 1. 
Table 1 - Chemical analysis of the soil used in the experiment (Haplortox)

\begin{tabular}{|c|c|c|c|c|c|c|c|c|c|}
\hline P Resine & $\mathrm{MO}$ & $\mathrm{pH}$ & $\mathrm{K}$ & $\mathrm{Ca}$ & $\mathrm{Mg}$ & $\mathrm{H}+\mathrm{Al}$ & SB & CTC & V \\
\hline$\left(\mathrm{mg} \mathrm{dm}^{-3}\right)$ & $\left(\mathrm{g} \mathrm{dm}^{-3}\right)$ & $\left(\mathrm{CaCl}^{2}\right)$ & \multicolumn{6}{|c|}{$\left(\mathrm{mmol}_{\mathrm{c}} \mathrm{dm}^{-3}\right)$} & $(\%)$ \\
\hline 16 & 32 & 5.5 & 2.6 & 27 & 11 & 31 & 40.6 & 71.6 & 57 \\
\hline
\end{tabular}

SB: sum of bases; CTC: cation exchange capacity; V: percent base saturation.

The fertilization of the substrate was based on soil analysis and fertilizer recommendations for alfalfa (Moreira et al., 2008). The soil was adjusted with lime (80\% TNP) and fertilized with potassium chloride $\left(60 \% \mathrm{~K}_{2} 0\right)$ super simple $\left(20 \% \mathrm{P}_{2} \mathrm{O}_{5}\right.$, $15 \% \mathrm{Ca} \% \mathrm{~S} 9)$ and FMA BR $12(9 \% \mathrm{Zn}, 3 \% \mathrm{Fe}$, $1.8 \% \mathrm{Bo}, 2.1 \% \mathrm{Mn}, 0.1 \% \mathrm{Mo}, 0.85 \% \mathrm{Cu})$.

The experimental design was completely randomized with three replications in a $4 \times 11+1$ factorial scheme, with eleven herbicides for use at post-emergence and four doses plus an untreated control. All treatments can be seen in Table 2 .

The sowing of alfalfa (cultivar Crioula) was performed 32 days after fertilization of the substrate, with five seeds being sown per pot, previously inoculated with Rhizobium meliloti. The alfalfa plants were irrigated throughout the experimental period in order to maintain soil moisture around $80 \%$ of field capacity.

Herbicide application was performed when the alfalfa plants had about 4-5 pairs of leaves at 33 days after the crop had been sown (DAS), with a $\mathrm{CO}_{2}$-pressurized backback sprayer outfitted with XR 11003 flat fan nozzles, with pressure of $30 \mathrm{Lb} /$ inches $^{2}$ and a flow rate of $200 \mathrm{~L} \mathrm{ha}^{-1}$. The application occurred in the morning, when the substrate of the pot was damp, the sky was clear, and the wind speed was below $4.0 \mathrm{~km} \mathrm{~h}^{-1}$. The average air temperature was $25.9{ }^{\circ} \mathrm{C}$.

The effects of treatments on alfalfa were evaluated at $7,14,21,28$ and 35 days after application (DAA), according to the visual symptoms of phytotoxicity on a scale of $0 \%$ (zero) to $100 \%$, where 0 (zero) corresponded to no visible injury to the plant and $100 \%$, to plant death. At 35 DAA, plant height was measured from the ground to the apical meristem. Dry mass of shoots and roots was also determined by weighing the material collected and dried in a forced circulation oven $\left(70 \pm 2{ }^{\circ} \mathrm{C}\right)$ for 72 hours until constant weight.

Data were subjected to analysis of variance and, when significant, qualitative means were compared by Tukey's test at 5\% probability; for the quantitative means, the regression curves were adjusted.

\section{Evaluation of the selectivity of herbicides applied to alfalfa crops at pre-emergence}

The sampling unit was represented by $5 \mathrm{~L}$ polyethylene pots, containing clayey Haportlox collected in the 0-20 cm layer, whose chemical analysis can be seen in Table 1. Similarly, soil was collected from an Oxisol, medium texture, whose chemical analysis is shown in Table 3. The fertilization of the substrate was based on soil analysis and fertilizer recommendations for alfalfa (Moreira et al., 2008).

The experimental design was completely randomized with five replications in a factorial $3 \times 4 \times 2$ scheme, with three herbicides for use at pre-emergence, four doses (and also the untreated control) and two types of soil texture

Table 2 - Treatments with post-emergent herbicides and their respective doses

\begin{tabular}{|l|r|r|r|r|}
\hline \multirow{2}{*}{ Treatment } & \multicolumn{4}{|c|}{ Dose $\left(\mathrm{g}\right.$ a.i. $\left.\mathrm{ha}^{-1}\right)$} \\
\cline { 2 - 5 } & $1.25 \mathrm{D}$ & $1.0 \mathrm{D}$ & $0.75 \mathrm{D}$ & $0.5 \mathrm{D}$ \\
\hline Fluazifop-p-butyl & 312.5 & 250.0 & 187.5 & 150.0 \\
\hline Clethodim & 105.0 & 84.0 & 63.0 & 42.0 \\
\hline Bentazon & 0.9 & 0.72 & 0.54 & 0.36 \\
\hline Chlorimuron-ethyl & 50.0 & 40.0 & 30.0 & 20.0 \\
\hline Fomesafen & 321.5 & 250 & 187.5 & 150.0 \\
\hline Saflufenacil & 0.125 & 0.10 & 0.075 & 0.05 \\
\hline Imazethapyr & 125.0 & 100.0 & 75.0 & 50.0 \\
\hline Nicosulfuron & 62.5 & 50.0 & 37.5 & 25.0 \\
\hline Haloxyfop-p-methyl & 75.0 & 60.0 & 45.0 & 30.0 \\
\hline MSMA & 1750.0 & 1400.0 & 1050.0 & 700.0 \\
\hline Imazaquin & 187.5 & 150 & 112.5 & 75.0 \\
\hline
\end{tabular}


Table 3 - Chemical analysis of the soil used in the experiment (medium texture)

\begin{tabular}{|c|c|c|c|c|c|c|c|c|c|c|}
\hline P Resine & MO & $\mathrm{pH}$ & $\mathrm{K}$ & $\mathrm{Ca}$ & $\mathrm{Mg}$ & $\mathrm{H}+\mathrm{Al}$ & $\mathrm{SB}$ & $\mathrm{CTC}$ & $\mathrm{V}$ \\
\hline$\left(\mathrm{mg} \mathrm{dm}^{-3}\right)$ & $\left(\mathrm{g} \mathrm{dm}^{-3}\right)$ & $\left(\mathrm{CaCl}^{2}\right)$ & \multicolumn{7}{|c|}{$\left(\mathrm{mmol}_{\mathrm{c}} \mathrm{dm}^{-3}\right)$} & $(\%)$ \\
\hline 4 & 26 & 4.4 & 2.9 & 7 & 3 & 42 & 12.9 & 54.9 & 23 \\
\hline
\end{tabular}

SB: sum of bases; CTC: cation exchange capacity; V: percent base saturation.

(clayey and medium). The products used and their respective doses can be seen in Table 4.

The herbicides were applied directly to the soil 15 days after the pots had been filled, using a $\mathrm{CO}_{2}$-pressurized backback sprayer outfitted with two XR 11003 flat fan nozzles, spaced at $0.50 \mathrm{~m}$, with pressure of $30 \mathrm{Lb}$ inches ${ }^{-2}$ and flow rate of $200 \mathrm{~L} \mathrm{ha}^{-1}$. During the application, in the morning, the substrate of the pot was damp, the sky clear, and the wind speed less than $4.0 \mathrm{~km} \mathrm{~h}^{-1}$. The average air temperature was $26^{\circ} \mathrm{C}$.

The sowing of alfalfa (cultivar Crioula) was held the day before herbicide application; eight seeds were sown per pot, and they were then inoculated with Rhizobium meliloti. The pots were irrigated throughout the experimental period in order to maintain soil moisture at around $80 \%$ of field capacity. To determine the selectivity of herbicides to alfalfa, the visual symptoms of phytotoxicity were evaluated at 14 and 28 days after germination of the plants (DAG). Scores were assigned according to a scale from $0 \%$ (no symptoms) to $100 \%$ (plant death); the dry biomass of shoots and roots was determined at 28 DAA, obtained by weighing the material collected and drying it in a forced circulation oven $\left(70 \pm 2{ }^{\circ} \mathrm{C}\right)$ for 72 hours until constant weight.

Data were subjected to analysis of variance and, when significant, qualitative means were compared by Tukey test at 5\%

Table 4 - Treatment with pre-emergent herbicides and their respective doses

\begin{tabular}{|l|r|r|r|c|}
\hline \multirow{2}{*}{\multicolumn{1}{|c|}{ Treatment }} & \multicolumn{4}{|c|}{ Dose $\left(\mathrm{g}\right.$ a.i. $\left.\mathrm{ha}^{-1}\right)$} \\
\cline { 2 - 5 } & $1.25 \mathrm{D}$ & \multicolumn{1}{c|}{$1.0 \mathrm{D}$} & $0.75 \mathrm{D}$ & $0.5 \mathrm{D}$ \\
\hline Hexazinone & 281.2 & 225.0 & 168.7 & 112.5 \\
\hline Atrazine + Simazine & 2187.5 & 1750.0 & 1312.5 & 875.0 \\
\hline S-metolachlor & 1800.0 & 1440.0 & 1080.0 & 720.0 \\
\hline
\end{tabular}

probability. The regression curves were adjusted to the quantitative means.

\section{Evaluation of the residual effect of herbicides applied to other crops on alfalfa grown in sequential season}

The sampling unit was composed of $5 \mathrm{~L}$ polyethylene pots, containing Haplortox collected in the $0-20 \mathrm{~cm}$ layer, whose chemical analysis is shown in Table 1 . The fertilization of the substrate was based on soil analysis and fertilizer recommendations for alfalfa (Moreira et al., 2008).

The experimental design was completely randomized in a $5 \times 4$ factorial scheme with five replications, with five herbicides (atrazine - 2,550 $\mathrm{g} \mathrm{ha}^{-1}$; clomazone - $600 \mathrm{~g} \mathrm{ha}^{-1}$; diclosulam - $25 \mathrm{~g} \mathrm{ha}^{-1}$; diuron + hexazinone 936 + $264 \mathrm{~g} \mathrm{ha}^{-1}$; diuron + hexazinone + sulfometuron $\left.-1,386+391+33.35 \mathrm{~g} \mathrm{ha}^{-1}\right)$ and four sowing dates for alfalfa $(15,30,60$ and 90 days after herbicide application - DAA). The herbicides were applied directly to the soil with a $\mathrm{CO}_{2}$-pressurized backback sprayer outfitted with two XR 11003 flat fan nozzles, spaced at $0.50 \mathrm{~m}$, with pressure of $30 \mathrm{Lb} /$ inches $^{2}$ and flow rate of $200 \mathrm{~L} \mathrm{ha}^{-1}$.

To determine the herbicide selectivity in alfalfa, the phytotoxicity symptoms were evaluated at $7,14,21$ and 28 days after germination (DAG). Scores were assigned according to a scale ranging from $0 \%$ (no symptoms) to $100 \%$ (plant death). The dry mass of shoots and roots was determined at 28 DAG, obtained by weighing the material collected and drying it in a forced circulation oven $\left(70 \pm 2{ }^{\circ} \mathrm{C}\right)$ for 72 hours.

Data were subjected to analysis of variance and, when significant, qualitative averages were compared by Tukey's test at 5\% probability. The regression curves were adjusted to the quantitative means. 


\section{RESULTS AND DISCUSSION}

\section{Evaluation of the selectivity of herbicides applied to alfalfa crops at post-emergence}

Slow phytotoxic effect was observed in the alfalfa plants treated with the herbicides chlorimuron-ethyl (Figure 1A), imazaquin (Figure 1B) and nicosulfuron (Figure 1C). The mechanism of action of these herbicides inhibits the enzyme acetolactate synthase (ALS) in plants, blocking the synthesis of aliphatic side chain amino acids such as valine, leucine and isoleucine. ALS inhibitors are characterized as systemic and can accumulate in the apical meristems, preventing the growth and development of sensitive plants, but visually, phytotoxicity is processed slowly (Shaner, 2003).

The herbicide chlorimuron-ethyl resulted in toxicity in alfalfa plants at around $40 \%$ at the commercial dose (1D) in the last assessment at $35 \mathrm{DAA}$, and $68 \%$ at the highest dose $(1.25 \mathrm{D})$, which may cause losses to producers (Figure 1A). It was observed that at the commercial dose, the plants recovered after at 14 DAA, when phytotoxicity reached $60 \%$. Silva et al. (2004) showed that alfalfa treated with chlorimuron-ethyl showed initial symptoms of phytotoxicity with full recovery after 14 DAA. Mello et al. (2000) obtained the same result, with less negative effects on alfalfa between the first and second cuts.

With regard to morphological parameters, statistical difference was observed in the dry mass of shoots and roots, with a negative effect at larger doses (Figure 3). The data corroborate research by Arregi et al. (2001), who observed phytotoxicity symptoms in alfalfa caused by chlorimuron, e.g. chlorosis, narrow leaves, deformed branches and retarded growth.

The herbicides imazaquin (Figure 1B) and nicosulfuron (Figure 1C) caused injuries from which plants have not recovered, and phytotoxicity symptoms were quite high and proportional with increasing doses of the herbicides. The highest dose of imazaquin (1.25 D) caused 90\% phytotoxicity and the commercial dose caused $75 \%$ phytotoxicity, which prevents the use of this herbicide in alfalfa. For nicosulfuron, phytotoxicity was less than $40 \%$ only at half of the recommended dose
(0.5 D). Progressive injuries to alfalfa up to around $100 \%$ were detected in all other treatments. There was no effect of dose for either herbicide on the root biomass of alfalfa plants (Figures 3B, C). With respect to shoot biomass, no significant differences were observed for imazaquin, but differences were observed for nicosulfuron, whose larger doses caused a decrease in biomass. In the study by Mello (2000), nicosulfuron provided reductions in dry matter yield over 96\%, which indicates high phytotoxicity to the crop.

The molecules of this class of herbicides are readily absorbed by the leaves and roots of the plants and transported both into the xylem and the phloem. ALS inhibitors are widely used in agriculture due to the wide range of crops to which they are selective, and such selectivity is based on the ability of the crop to metabolize these products before they cause damage to plants (Tan et al. 2005).

The symptoms caused by this type of herbicides are wrinkled leaves, death of apical buds, shoots from lateral buds, inhibition of root growth and reduced or even interrupted growth and development of the plant (Roman, 2007). However, phytotoxic symptoms are usually caused by doses above the recommended ones, as can be seen in (Figures 1A, C).

Some plant species, however, can recover from these stresses, depending on the degree of phytotoxicity, the level of injury and the stage of plant development. This recovery was observed when imazethapyr was applied at doses above $0.75 \mathrm{D}$ (Figure 1D) at 14 and 21 DAA. At 35 DAA, the symptom of phytotoxicity was $30 \%, 25 \%$ and $10 \%$ for the doses of $0.75 \mathrm{D}, 1.0 \mathrm{D}$ and $0.5 \mathrm{D}$, respectively. This behavior explains the fact that no significant difference occurred across treatments of this herbicide for plant height, shoot dry mass and root dry mass (Figure 3D). A similar result was found by Silva et al. (2004). However, the phytotoxicity symptom found by Mello et al. (2000) was considered as average, with decreased dry mass and lower plant development. Mesbah et al. (2005) found injuries to alfalfa due to phytotoxicity caused by the herbicides imazethapyr and imazamox after application to plants $15 \mathrm{~cm}$ tall. 

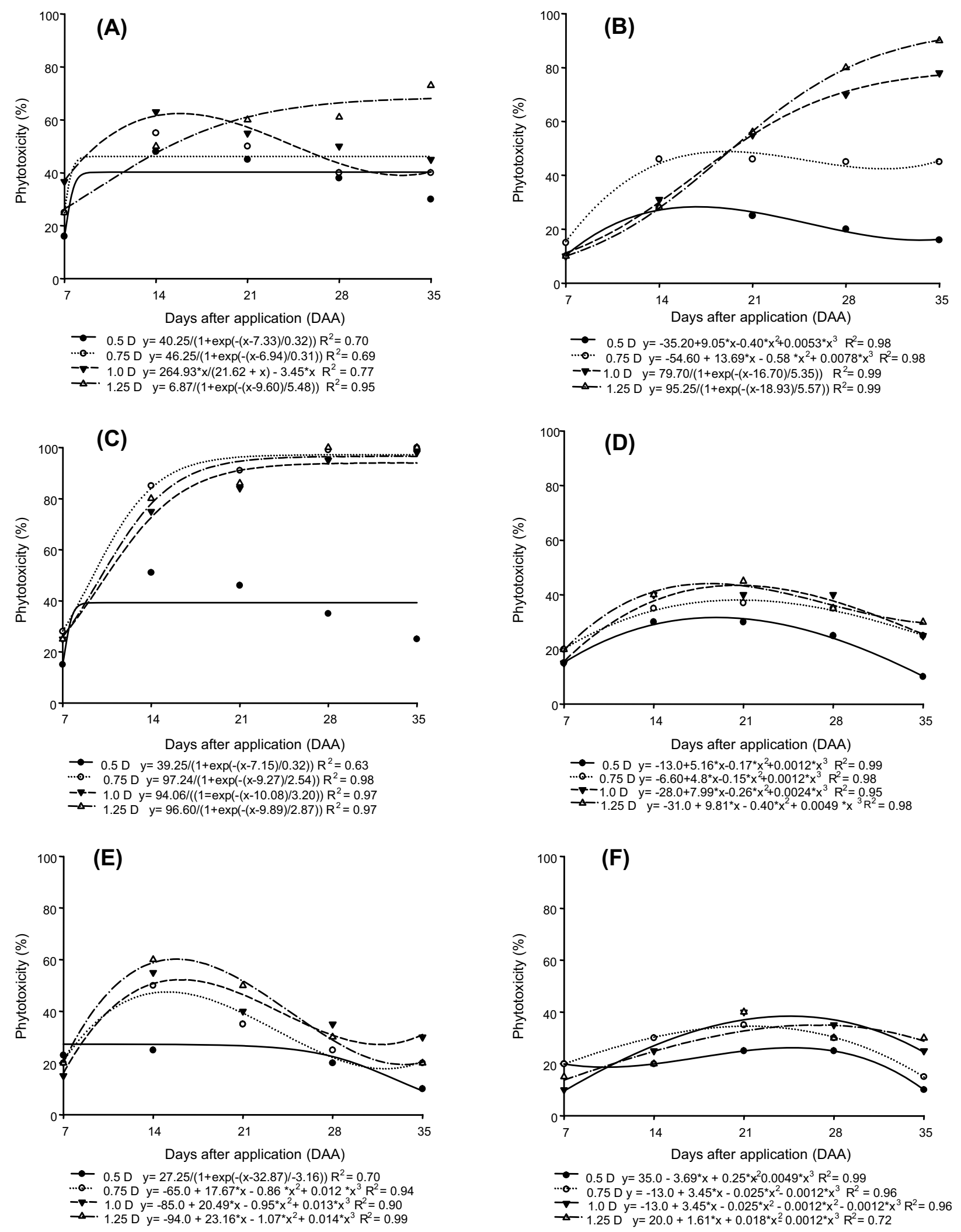

Figure 1 - Evaluation of the visual symptoms of phytotoxicity caused by herbicides chlorimuron-ethyl (A), imazaquin (B), nicosulfuron (C), imazethapyr (D), clethodim (E), haloxyfop-p-methyl (F) at different doses at 7, 14, 21, 28 and 35 DAA. 
The herbicides clethodim, fluazifop-p-butyl and haloxyfop-p-methyl are inhibitors of the enzyme acetyl CoA carboxylase (ACCase), which catalyzes the first step in the biosynthesis of fatty acids. These herbicides control only grass species and, with rare exceptions, act on dicotyledons, which make these compounds highly tolerant (Maneechote et al., 2005). Twidwell et al. (1994) observed a large accumulation of dry matter in alfalfa when weeds, mainly grasses, were effectively controlled with herbicides, which demonstrates their importance to alfalfa crops.

For clethodim (Figure 1D), phytotoxicity symptoms were approximately $20 \%$ for doses of 0.75 and $1.25 \mathrm{D}, 30 \%$ for the dose of $1.0 \mathrm{D}$ and $10 \%$ for the dose of $0.5 \mathrm{D}$, not influencing crop productivity economically, as can be seen by height and shoot dry mass, which were not influenced by the application of this herbicide (Figure 3E).

For haloxyfop-p-methyl, phytotoxicity scores remained low at all doses (Figure $1 \mathrm{~F}$ ), with no significant difference for the morphological parameters of the plants (Figure 3F).

However, fluazifop-P-butyl resulted in high phytotoxicity between 14 and 21 DAA, particularly at doses of $1.0 \mathrm{D}$ and $1.25 \mathrm{D}$, with decreased symptoms after 35 DAA (Figure 2A), which interfere with the height of the plants that had received the highest dose of the herbicide, while the dry mass of shoots and roots suffered no decrease compared to the control treatment (Figure 4A). Thus, this herbicide does not affect the formation of plant biomass, but it influenced plant height. The tolerance of crops to ACCase inhibiting herbicides has been reported mainly through three mechanisms. The first, and most common mechanism, is that in several eudicotyledonous species the ACCase enzyme is eukaryotic and insensitive to the herbicides (Gimenez-Espinosa et al., 1999). The second mechanism is the differential metabolism of herbicides, which are transformed into nontoxic forms (De Prado et al., 2000; Preston \& Mallory-Smith, 2001). Finally, selectivity could result from compartmentalizing or excluding the site of action of the herbicide, reducing absorption or translocation (or both) (De Prado et al. 2001).
In their research, Mello et al. (2000) concluded that haloxyfop-methyl, fluazifop-pbutyl and clethodim, all of which were ACCase inhibitors, were the most selective herbicides to alfalfa.

For the herbicide bentazon, whose mechanism of action inhibits photosystem II (PSII), a negative effect was observed for height and shoot biomass of alfalfa plants (Figure 4B). This fact can be attributed to the fast effect of this herbicide on the integrity of the membranes, leading to rapid and widespread leaf necrosis (Diebold et al. 2004). This also explains the high values of phytotoxicity symptom even at half of the commercial dose applied (Figure 2B).

Some crops, however, quickly metabolize the bentazon molecule into non-toxic forms, whereas susceptible plants do not possess this ability (Roman, 2007), as was found for alfalfa in this study. Mello et al. (2000) also reported phytotoxicity and reduction in plant size and in dry matter yield. However, in an experiment conducted by Silva et al. (2004), plants treated with bentazon showed initial symptoms of phytotoxicity with full recovery after 14 DAA and 90 DAA. There were no differences between plants treated with this herbicide and the control for the parameters shoot dry biomass accumulation and height.

Combinations of bentazon with imazamox or imazethapyr resulted in minor injuries to alfalfa crops $(9-13 \%)$ and better control of Cirsium arvensis L. (> 80\%) than when bentazon was used alone (Mesbah and Miller, 2005).

Saflufenacil is a herbicide which has been developed for use at pre-emergence, incorporated pre-planting or post-emergence in many crops, including sugar cane, corn, wheat, soybeans and cotton, especially for the control of eudicotyledons. This herbicide belongs to the pyrimidinedione family and inhibits the enzyme protoporphyrinogen oxidase (PROTOX) (Grossman et al. 2010). In plants treated with saflufenacil, phytotoxicity could be observed a few hours after application, and phytotoxicity symptoms increased when the dose administered also increased (Figure 2C). Plant height and dry mass of shoots and roots was inversely proportional to the increase of the applied dose (Figure 4C). 


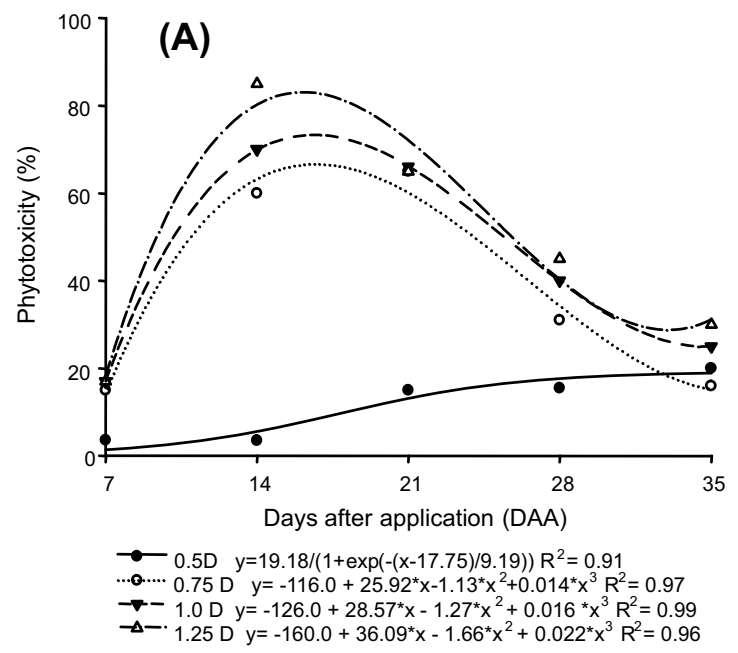

(C)

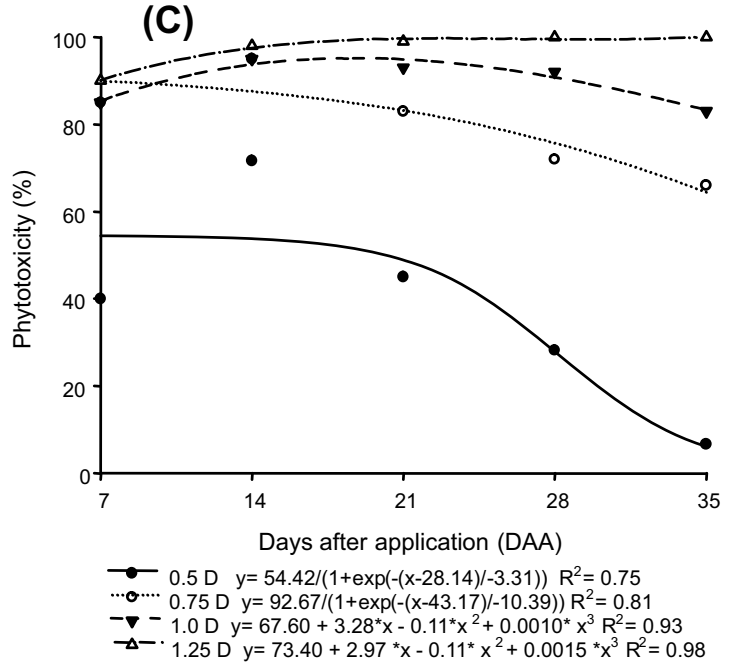

(B)

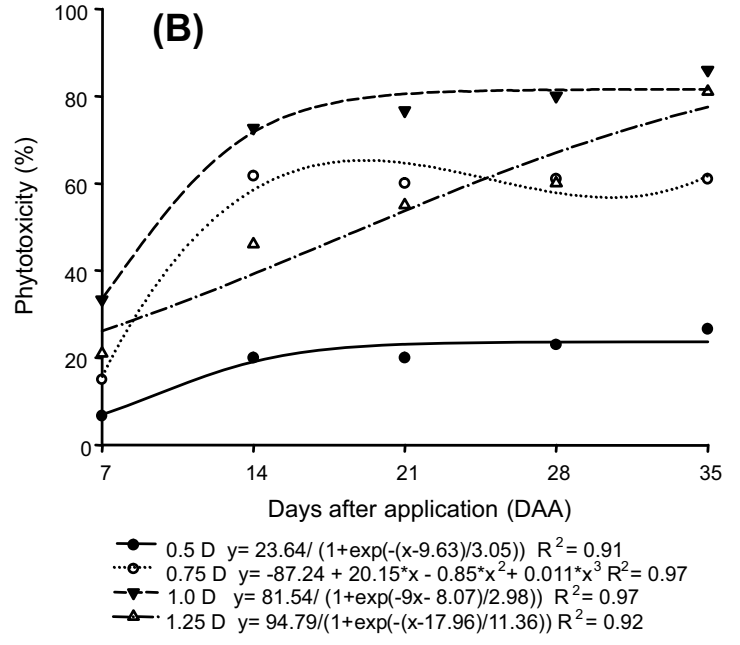

(D)

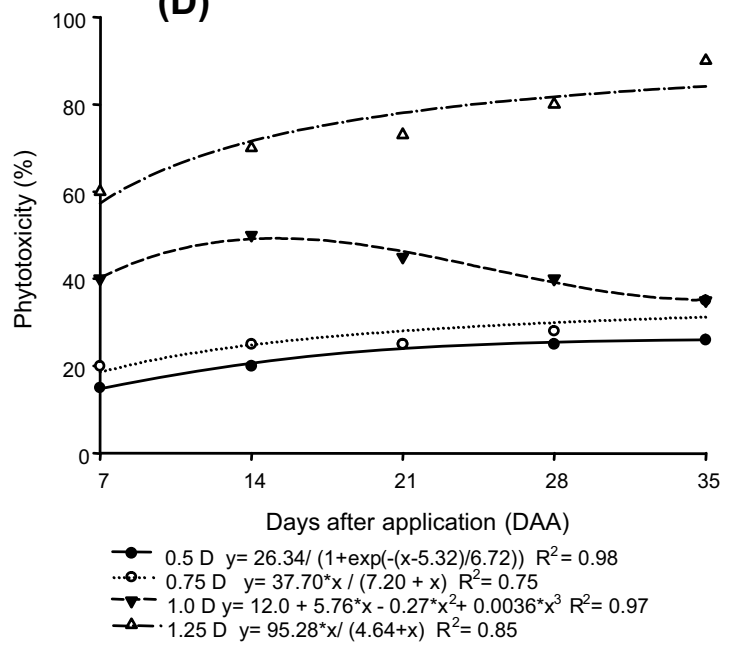

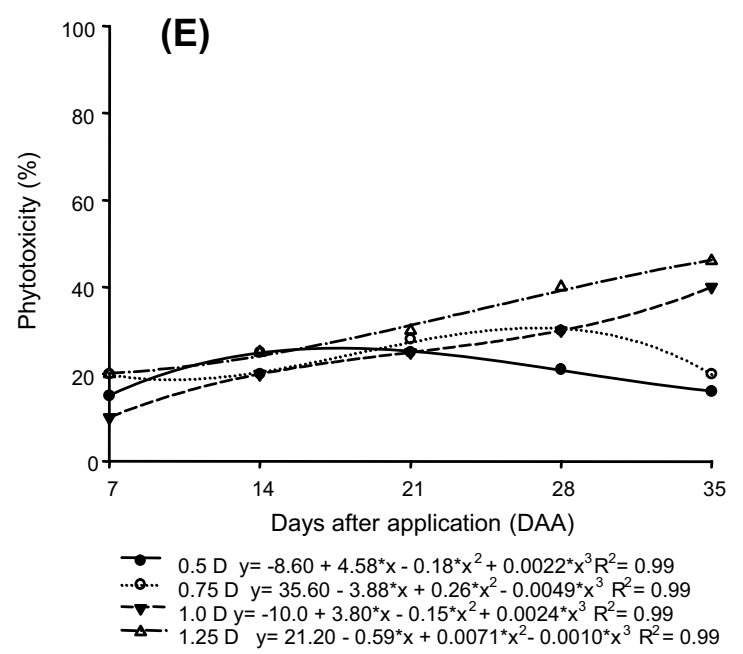

Figure 2 - Evaluation of the visual symptoms of phytotoxicity caused by fluazifop-p-butyl (A), bentazon (B), saflufenacil (C), fomesafen (D), MSMA (E) at different doses at 7, 14, 21, 28 and 35 DAA. 

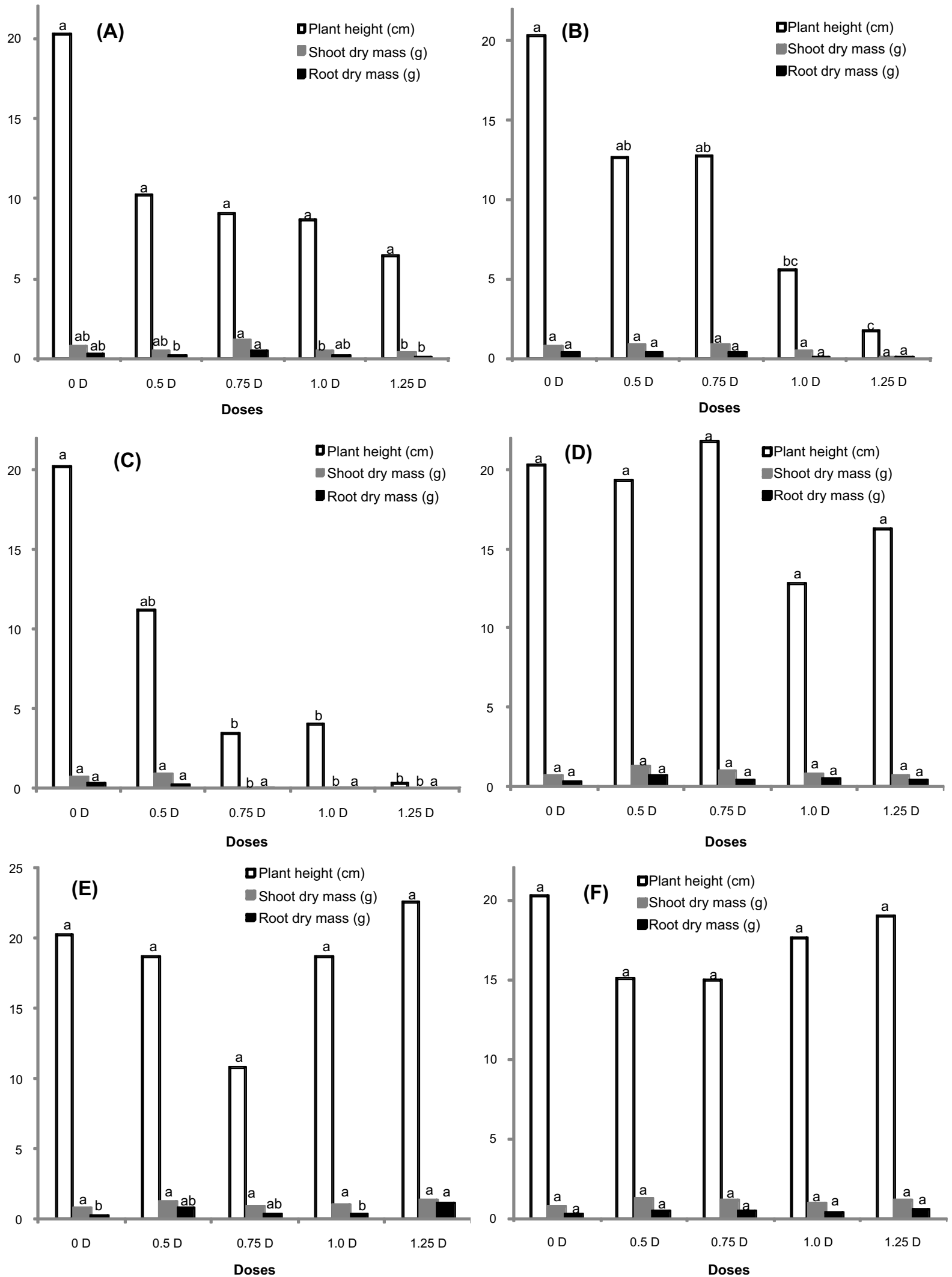

Figure 3 - Plant height (cm) and biomass of shoots and roots (g) of alfalfa plants after treatment with herbicides chlorimuron (A), imazaquin (B), nicosulfuron (C), imazethapyr (D), clethodim (E) and haloxyfop-p-methyl (F). 

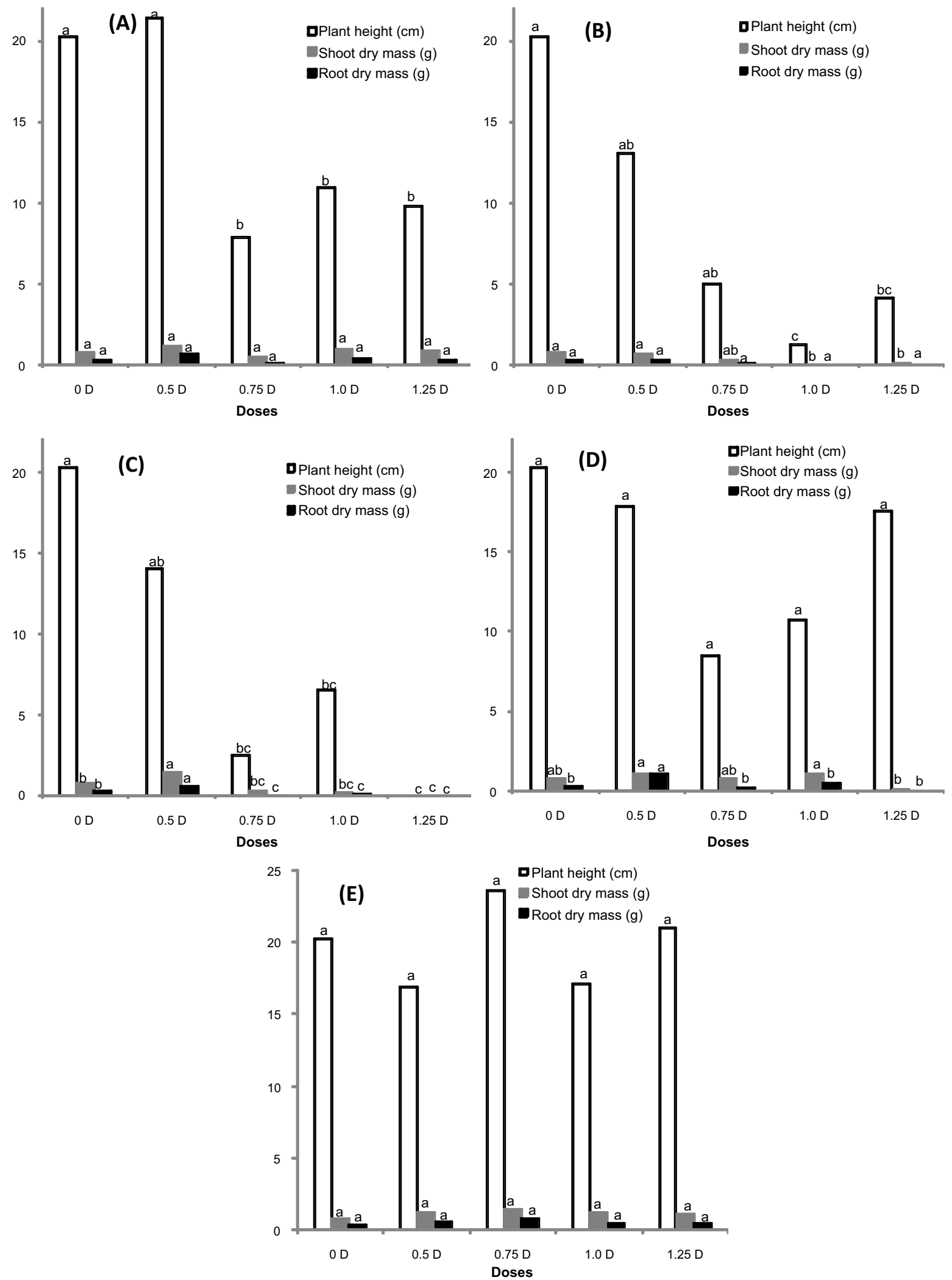

Figure 4 - Plant height (cm) and biomass of shoots and roots (g) of alfalfa after treatment with herbicides fluazifop-p-butyl (A), bentazon (B), saflufenacil (C), fomesafen (D) and MSMA (E). 
In plants treated with fomesafen, which also inhibits PROTOX, the symptom of phytotoxicity was greater in treatments of $1.0 \mathrm{D}$ and $1.25 \mathrm{D}$ throughout the experiment, and phytotoxicity reached $80 \%$ at the highest dose at 35 DAA (Figure 2D). There was no statistical difference in plant height across treatments, but a reduction was observed in shoot dry mass at the highest dose of the herbicide applied (Figure 4D). For Silva et al. (2004), the plants treated with fomesafen at 21 DAA still showed symptoms of toxicity; however, these injuries were restricted only to younger leaves, and not in the apical meristem, as verified by Silva et al. (2001). However, Mello (2000) observed a decrease in dry matter accumulation when fomesafen had been applied to alfalfa, as well as lower height compared to the control.

The herbicide MSMA controls a broad spectrum of grass and broadleaf weeds, and it is mainly absorbed through the leaves (Roman, 2007). Figure $2 \mathrm{E}$ shows the results of visual evaluations of phytotoxicity symptom, where the selective ability of the product is observed, as there were no symptoms that could result in economic losses. Plant height and plant dry mass of shoots and roots did not differ across treatments (Figure 4D).

From the data on phytotoxicity, plant height and biomass of roots and shoots, it can be concluded that the alfalfa plants were more tolerant to imazethapyr, clethodim, haloxyfopp-methyl, fomesafen and MSMA applied to the crop at post-emergence.

\section{Evaluation of the selectivity of herbicides applied to alfalfa crops at pre-emergence}

There was statistical difference compared to the control for herbicides hexazinone and atrazine + simazine, but no difference was observed across treatments, since no germination occurred in any of the herbicide treatments in both soil textures. Thus, zero biomass was obtained for the shoots and roots. Hexazinone at a dose of $420 \mathrm{~g} \mathrm{ha}^{-1}$ applied to previously established alfalfa resulted in a good weed control and a safe procedure for the crop; however, doses equal to or greater than $560 \mathrm{~g} \mathrm{ha}^{-1}$ caused injuries to alfalfa, suggesting that the selectivity of hexazinone largely depends on the dose and also whether or not the alfalfa crop had had a first cutting (Orlof $\&$ Wilson, 2008).

In phytotoxicity evaluations at 14 and 28 DAG in both soil textures, there was statistical difference between the control and the other treatments for the herbicide S-metolachlor. Greater phytotoxicity occurred in clayey soil in the $0.5 \mathrm{D}$ treatment, whereas in the medium soil texture, the symptom of phytotoxicity increased by increasing the dose administered (Table 5). However, when analyzing the biomass of shoots and roots, there were no significant differences across herbicide treatments or with respect to soil texture (Table 6). According to Silva et al. (2002), S-metolachlor may be applied to alfalfa until the dose $1.92 \mathrm{~kg} \mathrm{ha}^{-1}$, regardless of soil organic matter and soil $\mathrm{pH}$, with excellent control of broadleaved and grass weeds.

Table 5 - Evaluation of phytotoxicity in alfalfa plants after treatment with herbicide S-metolachlor at 14 and 28 GAD

\begin{tabular}{|c|c|c|c|c|}
\hline \multirow{2}{*}{ Treatment } & \multicolumn{4}{|c|}{ Phytotoxicity symptoms (\%) } \\
\cline { 2 - 5 } & \multicolumn{2}{|c|}{$14 \mathrm{DAG}$} & \multicolumn{2}{c|}{$28 \mathrm{DAG}$} \\
\cline { 2 - 5 } & Clayey Texture & Medium Texture & Clayey Texture & Medium Texture \\
\hline $0 \mathrm{~d}$ & $0.00 \mathrm{cA}$ & $0.00 \mathrm{cA}$ & $0.00 \mathrm{dA}$ & $0.00 \mathrm{cA}$ \\
\hline $0.5 \mathrm{~d}$ & $56.00 \mathrm{abA}$ & $40.00 \mathrm{bB}$ & $82.00 \mathrm{aA}$ & $40.00 \mathrm{bB}$ \\
\hline $0.75 \mathrm{~d}$ & $38.00 \mathrm{bA}$ & $40.00 \mathrm{bA}$ & $38.00 \mathrm{cA}$ & $43.00 \mathrm{bB}$ \\
\hline $1.0 \mathrm{~d}$ & $64.00 \mathrm{aA}$ & $43.00 \mathrm{abB}$ & $64.00 \mathrm{bA}$ & $60.00 \mathrm{aA}$ \\
\hline $1.25 \mathrm{~d}$ & $60.00 \mathrm{aA}$ & $60.00 \mathrm{aA}$ & $60.00 \mathrm{bA}$ & 20.04 \\
\hline CV (\%) & 26.98 & 26.80 & 22.50 & 13.16 \\
\hline LSD (5\%) & 14.83 & 6.34 & 5.05 \\
\hline
\end{tabular}

Equal lower-case letters in the column and capital letters in the lines do not differ significantly from each other according to the Tukey test at a $5 \%$ probability within each evaluation. 
Table 6 - Dry mass of plants after treatment with herbicide S-metolachlor at 28 DAG

\begin{tabular}{|c|c|c|c|c|}
\hline \multirow{2}{*}{ Treatment } & \multicolumn{2}{|c|}{ Shoot dry mass $(\mathrm{g})$} & \multicolumn{2}{c|}{ Dry mass of shoots + roots $(\mathrm{g})$} \\
\cline { 2 - 5 } & Clayey Texture & Medium Texture & Clayey Texture & Medium Texture \\
\hline $0 \mathrm{~d}$ & $0.02 \mathrm{aA}$ & $0.01 \mathrm{aB}$ & $0.03 \mathrm{aA}$ & $0.02 \mathrm{aB}$ \\
\hline $0.5 \mathrm{~d}$ & $0.01 \mathrm{bA}$ & $0.01 \mathrm{abA}$ & $0.01 \mathrm{bA}$ & $0.01 \mathrm{abA}$ \\
\hline $0.75 \mathrm{~d}$ & $0.01 \mathrm{bA}$ & $0.00 \mathrm{bA}$ & $0.01 \mathrm{bA}$ & $0.00 \mathrm{bA}$ \\
\hline $1 \mathrm{~d}$ & $0.01 \mathrm{bA}$ & $0.00 \mathrm{abA}$ & $0.01 \mathrm{bA}$ & $0.00 \mathrm{abA}$ \\
\hline $1.25 \mathrm{~d}$ & $0.01 \mathrm{bA}$ & $0.00 \mathrm{abA}$ & $0.01 \mathrm{bA}$ & $0.00 \mathrm{abA}$ \\
\hline CV $(\%)$ & 93.15 & 80.37 & 101.13 & 79.16 \\
\hline LSD $(5 \%)$ & 0.01 & 0.00 & 0.01 & 0.00 \\
\hline
\end{tabular}

Equal lower-case letters in the column and capital letters in the lines do not differ significantly from each other according to the Tukey test at a $5 \%$ probability within each evaluation.

However, in this study, although the plants have survived the S-metolachlor, there was a negative impact on biomass yield when compared to the control. Thus, it can be concluded that none of the pre-emergent herbicides tested were selective to alfalfa.

\section{Evaluation of the residual effect of herbicides on other crops applied on alfalfa grown in sequential season}

Figure 5 shows the results of the evaluations of phytotoxicity at 28 DAG in each sowing period of alfalfa after application of residual herbicides $(0,15,30,60$ and 90 DAA of the herbicides). A reduction was observed in phytotoxicity symptoms with increasing time between application and planting, except for sulfometuron + hexazinone + diuron, which caused $80 \%$ higher phytotoxicity at 90 DAA than at 60 DAA. For the herbicide clomazone, atrazine, hexazinone + diuron + diclosulam, phytotoxicity was observed at or below $40 \%$ at 90 DAA. However, it should be noted that until 30 DAA, all herbicides caused a carryover effect in the alfalfa crop, with injuries ranging from 80 to $100 \%$. After this period, the decrease in phytotoxicity occurred in all treatments, but in different patterns.

Table 7 shows the effect of the herbicide atrazine on biomass yield of shoots and roots of alfalfa. For shoot dry mass in treatments at 60 and 90 DAA, there was an increase in biomass compared to previous treatments and there were no statistical differences compared with the control. Production by roots was also higher in later sowings, with no significant differences compared with the control. Alfalfa is sensitive to atrazine, and seedlings can be poisoned and destroyed by the presence of residues of this herbicide in the soil (Kells et al. 1990). Several factors can affect the dissipation of atrazine in soils, such as $\mathrm{pH}$ (it is more persistent in soils with high $\mathrm{pH}$ ), temperature (the higher the temperature, the greater the degradation) and presence of microorganisms (Kells et al., 1990).

It can be seen that there was no statistical difference in biomass production between treatments involving different doses of sulfometuron + hexazinone + diuron, until 90 DAA (Table 8). However, compared with control, there were significant differences up to sowing performed at $30 \mathrm{DAA}$.

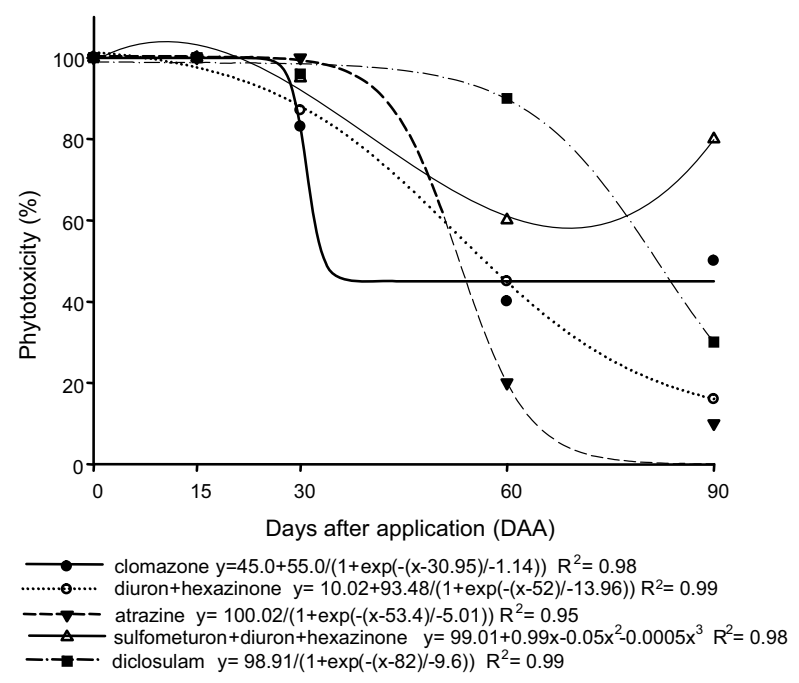

Figure 5 - Evaluation of the visual symptoms of toxicity in alfalfa plants sown at different dates after herbicide application. 
Table 7 - Dry mass of shoots and roots of alfalfa plants after treatment with atrazine at 28 DAG

\begin{tabular}{|c|c|c|c|c|c|c|}
\hline \multirow{2}{*}{ Treatment } & \multicolumn{2}{|c|}{ Shoot dry mass $(\mathrm{g})$} & \multicolumn{2}{|c|}{ Root dry mass (g) } & \multicolumn{2}{|c|}{ Dry mass of shoots + roots $(\mathrm{g})$} \\
\hline & Control & Atrazine & Control & Atrazine & Control & Atrazine \\
\hline $0 \mathrm{DAA}$ & $0.05 \mathrm{aA}$ & $0.00 \mathrm{aB}$ & $0.05 \mathrm{aA}$ & $0.00 \mathrm{aB}$ & $0.10 \mathrm{aA}$ & $0.00 \mathrm{bB}$ \\
\hline $15 \mathrm{DAA}$ & $0.06 \mathrm{aA}$ & $0.00 \mathrm{aB}$ & $0.05 \mathrm{aA}$ & $0.00 \mathrm{aB}$ & $0.11 \mathrm{aA}$ & $0.00 \mathrm{bB}$ \\
\hline $30 \mathrm{DAA}$ & $0.05 \mathrm{aA}$ & $0.00 \mathrm{aB}$ & $0.03 \mathrm{abA}$ & $0.00 \mathrm{aB}$ & $0.08 \mathrm{abA}$ & $0.00 \mathrm{bB}$ \\
\hline $60 \mathrm{DAA}$ & $0.02 \mathrm{aA}$ & $0.04 \mathrm{aA}$ & $0.01 \mathrm{bA}$ & $0.02 \mathrm{aA}$ & $0.03 \mathrm{bA}$ & $0.06 \mathrm{aA}$ \\
\hline 90 DAA & $0.02 \mathrm{aA}$ & $0.01 \mathrm{abA}$ & $0.01 \mathrm{bA}$ & $0.01 \mathrm{aA}$ & $0.03 \mathrm{bA}$ & $0.01 \mathrm{bA}$ \\
\hline $\mathrm{CV}(\%)$ & 94.89 & 76.25 & 113.53 & 101.03 & 99.23 & 82.50 \\
\hline $\operatorname{LSD}(5 \%)$ & 0.03 & 0.01 & 0.02 & 0.01 & 0.06 & 0.02 \\
\hline
\end{tabular}

Equal lower-case letters in the column and capital letters in the lines do not differ significantly from each other according to the Tukey test at a $5 \%$ probability within each evaluation.

Table 8 - Dry mass of shoots and roots of alfalfa plants after treatment with sulfometuron + hexazinone + diuron $(\mathrm{S}+\mathrm{D}+\mathrm{H})$ at $28 \mathrm{DAG}$

\begin{tabular}{|c|c|c|c|c|c|c|}
\hline \multirow{2}{*}{ Treatment } & \multicolumn{2}{|c|}{ Shoot dry mass $(\mathrm{g})$} & \multicolumn{2}{|c|}{ Root dry mass (g) } & \multicolumn{2}{|c|}{ Dry mass of shoots + roots $(\mathrm{g})$} \\
\hline & Control & $(\mathrm{S}+\mathrm{D}+\mathrm{H})$ & Control & $(\mathrm{S}+\mathrm{D}+\mathrm{H})$ & Control & $(\mathrm{S}+\mathrm{D}+\mathrm{H})$ \\
\hline 0 DAA & $0.05 \mathrm{aA}$ & $0.00 \mathrm{aB}$ & $0.04 \mathrm{aA}$ & $0.00 \mathrm{aB}$ & $0.09 \mathrm{aA}$ & $0.00 \mathrm{aB}$ \\
\hline 15 DAA & $0.06 \mathrm{aA}$ & $0.00 \mathrm{aB}$ & $0.05 \mathrm{aA}$ & $0.00 \mathrm{aB}$ & $0.11 \mathrm{aA}$ & $0.00 \mathrm{aB}$ \\
\hline 30 DAA & $0.05 \mathrm{aA}$ & $0.00 \mathrm{aB}$ & $0.03 \mathrm{abA}$ & $0.00 \mathrm{aB}$ & $0.08 \mathrm{abA}$ & $0.00 \mathrm{aB}$ \\
\hline 60 DAA & $0.02 \mathrm{aA}$ & $0.02 \mathrm{aA}$ & $0.01 \mathrm{bA}$ & $0.01 \mathrm{aA}$ & $0.03 \mathrm{bA}$ & $0.04 \mathrm{aA}$ \\
\hline 90 DAA & $0.02 \mathrm{bA}$ & $0.01 \mathrm{aA}$ & $0.01 \mathrm{bA}$ & $0.01 \mathrm{aA}$ & $0.03 \mathrm{bA}$ & $0.02 \mathrm{aA}$ \\
\hline CV $(\%)$ & 90.01 & 89.70 & 104.80 & 110.69 & 93.17 & 95.08 \\
\hline $\operatorname{LSD}(5 \%)$ & 0.03 & 0.01 & 0.02 & 0.01 & 0.05 & 0.02 \\
\hline
\end{tabular}

Equal lower-case letters in the column and capital letters in the lines do not differ significantly from each other according to the Tukey test at a $5 \%$ probability within each evaluation.

Regarding the use of diuron + hexazinone, a pronounced effect of the herbicide was observed until 30 DAA, especially regarding the production of shoot biomass (Table 9). From 60 DAA, further growth of alfalfa could be observed, confirming the results shown in Figure 5.

There was a pronounced negative effect of diclosulam on alfalfa plants until 60 DAA (Table 10). The application of diclosulam, when compared with other herbicides, occurs at very low doses ranging from 25 to $35 \mathrm{~g}$ a.i. ha- ${ }^{-1}$ (Rodrigues \& Almeida, 2011). However, according to Yoder et al. (2000), the application of this herbicide in soybeans could eventually cause injury to subsequent crops. For this reason, Rodrigues \& Almeida (2011) showed that areas treated with diclosulam should not be grown for some crops such as sunflower and brassica.
Table 11 shows that there was an increase in the biomass of plants treated with the herbicide clomazone when they had been sown after 60 DAA. Clomazone is moderately persistent in the soil, with a half-life ranging from 5 to 29 days, and 19 days on average, depending on the type of soil (Kirksey et al. 1996). Gallaher \& Mueller (1996), in a study conducted for two years under different environmental conditions, reported half-life of 55 days for this herbicide. Herbicides applied to the surface of the soil are often lost due to various factors, such as photobleaching, volatilization - accentuated by the high temperature on the soil surface, chemical and biological degradation and adsorption, which should be considered when accounting for the dissipation of the herbicide into the soil (Smith et al. 2007).

From the data collected, there is a difference in sensitivity of alfalfa plants to the 
Table 9 - Dry mass of shoots and roots of alfalfa plants after treatment with diuron + hexazinone (D + H) at 28 DAG

\begin{tabular}{|c|c|c|c|c|c|c|}
\hline \multirow{2}{*}{ Treatment } & \multicolumn{2}{|c|}{ Shoot dry mass (g) } & \multicolumn{2}{|c|}{ Root dry mass (g) } & \multicolumn{2}{|c|}{ Dry mass of shoots + roots $(\mathrm{g})$} \\
\hline & Control & $\mathrm{D}+\mathrm{H}$ & Control & $\mathrm{D}+\mathrm{H}$ & Control & $\mathrm{D}+\mathrm{H}$ \\
\hline $0 \mathrm{DAA}$ & $0.05 \mathrm{aA}$ & $0.00 \mathrm{bB}$ & $0.03 \mathrm{abA}$ & $0.00 \mathrm{aB}$ & $0.08 \mathrm{abA}$ & $0.00 \mathrm{aB}$ \\
\hline $15 \mathrm{DAA}$ & $0.06 \mathrm{aA}$ & $0.00 \mathrm{bB}$ & $0.05 \mathrm{aA}$ & $0.00 \mathrm{aB}$ & $0.11 \mathrm{aA}$ & $0.00 \mathrm{aB}$ \\
\hline 30 DAA & $0.05 \mathrm{aA}$ & $0.00 \mathrm{bB}$ & $0.03 \mathrm{abA}$ & $0.00 \mathrm{aB}$ & $0.08 \mathrm{abA}$ & $0.00 \mathrm{aB}$ \\
\hline $60 \mathrm{DAA}$ & $0.02 \mathrm{aA}$ & $0.03 \mathrm{aA}$ & $0.01 \mathrm{bA}$ & $0.01 \mathrm{aA}$ & $0.03 \mathrm{bA}$ & $0.05 \mathrm{aA}$ \\
\hline 90 DAA & $0.02 \mathrm{aA}$ & $0.01 \mathrm{abA}$ & $0.01 \mathrm{bA}$ & $0.01 \mathrm{aA}$ & $0.03 \mathrm{bA}$ & $0.01 \mathrm{aA}$ \\
\hline CV $(\%)$ & 89.82 & 86.28 & 109.26 & 108.21 & 93.64 & 90.47 \\
\hline $\operatorname{LSD}(5 \%)$ & 0.03 & 0.02 & 0.02 & 0.01 & 0.05 & 0.02 \\
\hline
\end{tabular}

Equal lower-case letters in the column and capital letters in the lines do not differ significantly from each other according to the Tukey test at a $5 \%$ probability within each evaluation.

Table 10 - Dry mass of shoots and roots of alfalfa plants after treatment with diclosulam at 28 DAG

\begin{tabular}{|c|c|c|c|c|c|c|}
\hline \multirow{2}{*}{ Treatment } & \multicolumn{2}{|c|}{ Shoot dry mass (g) } & \multicolumn{2}{|c|}{ Root dry mass (g) } & \multicolumn{2}{|c|}{ Dry mass of shoots + roots $(\mathrm{g})$} \\
\hline & Control & Diclosulam & Control & Diclosulam & Control & Diclosulam \\
\hline $0 \mathrm{DAA}$ & $0.05 \mathrm{aA}$ & $0.00 \mathrm{aB}$ & $0.05 \mathrm{aA}$ & $0.00 \mathrm{aB}$ & $0.010 \mathrm{aA}$ & $0.00 \mathrm{aB}$ \\
\hline $15 \mathrm{DAA}$ & $0.06 \mathrm{aA}$ & $0.00 \mathrm{aB}$ & $0.05 \mathrm{aA}$ & $0.00 \mathrm{aB}$ & $0.11 \mathrm{aA}$ & $0.00 \mathrm{aB}$ \\
\hline $30 \mathrm{DAA}$ & $0.05 \mathrm{abA}$ & $0.00 \mathrm{aB}$ & $0.03 \mathrm{abA}$ & $0.00 \mathrm{aB}$ & $0.08 \mathrm{abA}$ & $0.00 \mathrm{aB}$ \\
\hline 60 DAA & $0.02 \mathrm{bA}$ & $0.00 \mathrm{aB}$ & $0.01 \mathrm{bA}$ & $0.00 \mathrm{aA}$ & $0.03 \mathrm{bA}$ & $0.00 \mathrm{aB}$ \\
\hline $90 \mathrm{DAA}$ & $0.02 \mathrm{bA}$ & $0.01 \mathrm{aA}$ & $0.01 \mathrm{bA}$ & $0.01 \mathrm{aA}$ & $0.03 \mathrm{bA}$ & $0.02 \mathrm{aA}$ \\
\hline $\mathrm{CV}(\%)$ & 96.52 & 93.99 & 117.72 & 112.27 & 102.18 & 97.20 \\
\hline $\operatorname{LSD}(5 \%)$ & 0.03 & 0.01 & 0.02 & 0.01 & 0.05 & 0.02 \\
\hline
\end{tabular}

Equal lower-case letters in the column and capital letters in the lines do not differ significantly from each other according to the Tukey test at a $5 \%$ probability within each evaluation.

Table 11 - Dry mass of shoots and roots of alfalfa plants after treatment with clomazone at 28 DAG

\begin{tabular}{|c|c|c|c|c|c|c|}
\hline \multirow{2}{*}{ Treatment } & \multicolumn{2}{|c|}{ Shoot dry mass (g) } & \multicolumn{2}{|c|}{ Root dry mass (g) } & \multicolumn{2}{|c|}{ Dry mass of shoots + roots $(\mathrm{g})$} \\
\hline & Control & Clomazone & Control & Clomazone & Control & Clomazone \\
\hline $0 \mathrm{DAA}$ & $0.05 \mathrm{aA}$ & $0.00 \mathrm{aB}$ & $0.04 \mathrm{aA}$ & $0.00 \mathrm{aB}$ & $0.09 \mathrm{aA}$ & $0.00 \mathrm{aB}$ \\
\hline $15 \mathrm{DAA}$ & $0.06 \mathrm{aA}$ & $0.00 \mathrm{aB}$ & $0.05 \mathrm{aA}$ & $0.00 \mathrm{aB}$ & $0.11 \mathrm{aA}$ & $0.00 \mathrm{aB}$ \\
\hline $30 \mathrm{DAA}$ & $0.05 \mathrm{aA}$ & $0.01 \mathrm{aB}$ & $0.03 \mathrm{abA}$ & $0.00 \mathrm{aB}$ & $0.08 \mathrm{abA}$ & $0.01 \mathrm{aB}$ \\
\hline $60 \mathrm{DAA}$ & $0.02 \mathrm{aA}$ & $0.04 \mathrm{aA}$ & $0.01 \mathrm{ba}$ & $0.01 \mathrm{aA}$ & $0.03 \mathrm{bA}$ & $0.05 \mathrm{aA}$ \\
\hline 90 DAA & $0.02 \mathrm{aA}$ & $0.01 \mathrm{aA}$ & $0.01 \mathrm{bA}$ & $0.00 \mathrm{aA}$ & $0.03 \mathrm{bA}$ & $0.01 \mathrm{aA}$ \\
\hline $\mathrm{CV}(\%)$ & 90.80 & 78.99 & 108.81 & 106.23 & 93.50 & 86.42 \\
\hline $\operatorname{LSD}(5 \%)$ & 0.03 & 0.01 & 0.02 & 0.01 & 0.05 & 0.02 \\
\hline
\end{tabular}

Equal lower-case letters in the column and capital letters in the lines do not differ significantly from each other according to the Tukey test at a $5 \%$ probability within each evaluation.

herbicides used during the different times of sowing, and at $90 \mathrm{DAA}$, diclosulam herbicides, atrazine and diuron + hexazinone caused less phytotoxicity.

Planta Daninha, Viçosa-MG, v. 31, n. 4, p. 903-918, 2013

\section{LITERATURE CITED}

ARREGI, M.C.; SÁNCHEZ, D.; SCOTTA, R. Weed control in established alfalfa (Medicago sativa) with post emergence herbicides. Weed Technol., v. 15, n. 3, p. 424-428, 2001. 
DE PRADO, R. et al. Resistance to acetyl CoA carboxylaseinhibiting herbicides in Lolium multiflorum. Weed Sci., v. 48, n. 2, p. 311-318, 2000.

DE PRADO, R. et al. Is diclofop-methyl resistance in Lolium rigidum associated with a lack of penetration? Proc. Crop Protec. Conf. Weeds, v. 8, n. 2, p. 545-550, 2001.

DIEBOLD, S. et al. Sweet corn cultivar sensitivity to bentazon source. Weed Technol., v. 18, n. 4, p. 982-987, 2004.

\section{EMPRESA BRASILEIRA DE PESQUISA} AGROPECUÁRIA - EMBRAPA. Centro Nacional de Pesquisa de Solos. Sistema brasileiro de classificação de solos. Brasília: Embrapa Produção da Informação/Rio de Janeiro: Embrapa Solos, 1999. 412 p.

FONTES, P. C. R.; VILELA, D.; MARTINS, C. M. Estabelecimento da cultura da alfafa. In: CARVALHO, L. A.; VILELA, D. Cultura da alfafa: estabelecimento, fenação, custo de produção e construção de um secador estático. São Carlos: Embrapa, 1994. p. 1-11.

GALLAHER, K.; MUELLER, T. C. Effect of crop presence on persistence of atrazine, metribuzin, and clomazone in surface soils. Weed Sci., v. 44, n. 3, p. 698-703, 1996.

GIMENEZ-ESPINOSA, R. et al. Propaquizafop absorption, translocation, metabolism, and effect on acetyl-CoA carboxylase isoforms in chickpea (Cicer arietinum L.). Pestic. Biochem. Physiol., v. 65, n. 1, p. 140-150, 1999.

GROSSMAN, K. et al. The herbicide saflufenacil (KixorTM) is a new inhibitor of otoporphyrinogen IX oxidase activity. Weed Sci., v. 58, n. 1, p. 1-9, 2010.

KELLS, J. J. et al. Effect of atrazine and tillage on alfalfa (Medicago sativa) establishment in corn (Zea mays) alfalfa rotation. Weed Technol., v. 14, n. 2, p. 360-365, 1990.

KIRKSEY, K. B. et al. Clomazone dissipation in two Tennessee soils. Weed Sci., v. 44, n. 4, p. 959-963, 1996.

MANEECHOTE, C. et al. Resistance to ACCase-inhibiting herbicides in sprangletop (Leptochloa chinensis). Weed Sci., v. 53, n. 2, p. 290-295, 2005.

MESBAH, A. et al. Canada Thistle (Cirsium arvense) control in established alfalfa (medicago sativa) grown for seed production. Weed Technol., v. 19, n. 4, p. 1025-1029, 2005.

MELLO, G. et al. Seletividade de herbicidas, aplicados em pós-emergência, às plantas de alfafa. Planta Daninha, v. 18, n. 2, p. 323-330, 2000.
MOREIRA, A.; BERNARDI, A. C. C.; RASSINI, J. B. Correção do solo, estado nutricional e adubação da alfafa. In: FERREIRA, R. P. et al. (Ed.). Cultivo e utilização da alfafa nos trópicos. Brasília: Embrapa Transferência de Tecnologia, 2008. p. 81-124.

PRESTON, C.; MALLORY-SMITH, C. A. Biochemical mechanism, inheritance, and molecular genetics of herbicide resistance in weeds. In: POWLES, S. B.; SHANER, D. L., (Ed.) Herbicide resistance and world grains. Boca Raton: CRC, 2001. p.308.

RASSINI, J. B.; FREITAS, A. R.; DE PRADO, R. Efeitos de interferência de plantas daninhas no rendimento da cultura da alfafa. R. Soc. Bras. Zootec., v. 24, n. 4, p. 502-509, 1995.

RASSINI, J. B. et al. Cultivo da alfafa. 2.ed. São Carlos: Embrapa Pecuária Sudeste, 2007. (Sistemas de Produção, 1)

RODRIGUES, B. N.; ALMEIDA, F. S. Guia de herbicidas. Londrina: IAPAR, 2011. 697 p.

ROMAN, E. S. Como funcionam os herbicidas: da biologia à aplicação. Passo Fundo: Berthier, 2007. 160 p.

SHANER D. L. Herbicide safety relative to common targets in plants and mammals. Pest Manag. Sci., v. 60, n. 1, p. 17-24, 2003.

SILVA, W. et al. Tolerância da alfafa (Medicago sativa L.) a diferentes herbicidas aplicados em pré-emergência e pós-emergência. R. Ceres, v. 48, n. 278, p. 415-425, 2001.

SILVA, W. et al. Herbicidas na cultura da alfafa. R. Ceres, v. 49, n. 284, p. 405-418, 2002.

SILVA, W. et al. Avaliação da eficiência de herbicidas no controle de plantas daninhas em alfafa. Ci. Agrotéc., v. 28, n. 4, p. 729-735, 2004.

SILVA, A. et al. Herbicidas: comportamento no solo. In: SILVA, A.; SILVA, J. F. (Ed.). Tópicos em manejo de plantas daninhas. Viçosa, MG: Universidade Federal de Viçosa, 2007. p. 189-248.

TAN, S. et al. Imidazolinone tolerant crops: history, current status and future. Pest Manag. Sci., v. 61, n. 3, p. 246-257, 2005.

TWIDWELL, E. K. et al. Quackgrass control in established alfalfa with sethoxydim. Canadian J. Plant Sci., v. 74, n. 5, p. 647-651, 1994.

ZIMDAHL, R. L. The effect of competition duration. In: ZIMDAHL, R. L. (Ed).Weed crop competition. London: Blackwell, 2004. p. 109-130.

Planta Daninha, Viçosa-MG, v. 31, n. 4, p. 903-918, 2013 
WILSON, R. G.; ORLOFF, S. B. Winter annual weed control with herbicides in alfalfa-orchardgrass mixtures. Weed Technol., v. 22, n. 1, p. 30-33, 2008.
YODER, R. N. et al. Aerobic metabolism of diclosulam on U.S. and South American soils. J. Agric. Food Chem., v. 48, n. 1, p. 4335-4340, 2000. 